\title{
Effective Use of Information Sources for Breast Cancer Care: Interplay of Mass Media and Interpersonal Channels
}

\author{
Okorie Nelson $^{1}$, Oyesomi Kehinde $^{2}$, Olusola Oyero ${ }^{3}$, Olatunji Rotimi Wiliams ${ }^{4}$ \\ and Ebenezer Oludayo Soola \\ ${ }^{1,2,3}$ Department of Mass Communication, School of Human Resource Development, \\ College of Development Studies \\ ${ }^{4}$ Department of Public Relations and Advertising, Adebola Adegunwa School of Communication \\ Lagos State University, Ojo, Nigeria \\ ${ }^{5}$ Mass Communication, Department of Communication Art, University of Ibadan, Oyo State, Nigeria
}

Correspondence should be addressed to: Okorie Nelson; nelson.okorie@covenantuniversity.edu.ng

Received date: 15 September 2013; Accepted date: 8 January 2014; Published date: 13 June 2014

Academic Editor: Madalina Dociu

Copyright @ 2014. Okorie Nelson, Oyesomi Kehinde, Olusola Oyero, Olatunji Rotimi Wiliams and Ebenezer Oludayo Soola. Distributed under Creative Commons CC-BY 3.0

\begin{abstract}
In health communication research studies, there have been various qualitative and quantitative studies on breast cancer. However, there is paucity of research investigations on the influence of information sources used in media awareness campaigns on breast cancer care among women in Nigeria. This study, therefore, investigated the influence of media awareness campaigns on breast cancer care among women in South-West Nigeria. This study was anchored on two theories: agenda setting theory and diffusion of innovation theory. It employed survey design, which made use of the questionnaire to achieve the objectives of the study. The total number of subjects examined in this study was 600 questionnaire respondents. The multi- stage sampling and simple random sampling techniques were used to select the questionnaire respondents in Lagos, Oyo and Ekiti States. Three hypotheses were tested using cross tabulation and correlation analysis to determine the strength, nature and direction between variables. The findings revealed that the majority of the respondents (98.8\%) were aware of breast cancer but many of these respondents were not sufficiently knowledgeable of the disease. It also reveals that information sources such as mass media and interpersonal channels are crucial health communication carriers for breast cancer interventions. It was suggested that mass media messages should be incorporated as key machineries in media awareness campaigns for improving breast cancer care among women. This is essential because mass media messages can produce positive changes or prevent negative changes in health-related behaviours of women in South-West Nigeria.
\end{abstract}

Keyword: information sources, breast cancer, women and Nigeria

Cite this Article as: Okorie Nelson, Oyesomi Kehinde, Olusola Oyero, Olatunji Rotimi Wiliams

and Ebenezer Oludayo Soola (2014), " Effective Use of Information Sources for Breast Cancer Care: Interplay of Mass Media and Interpersonal Channels ", Journal of African Research in Business \& Technology, Vol. 2014 (2014), Article ID 152107, DOI: 10.5171/2014.152107 


\section{Introduction}

In the sphere of health communication, information sources are essential for health promotion and education. Scholars agree that information sources are essential in public health campaigns because they are seen as the cornerstone for health communication interventions (Kreps \& Sivaram, 2009; Okorie, 2011).

In any discussion on the effective use of information sources in public health campaigns to promote breast cancer care, the actual and potential roles of the mass media and interpersonal channels have long been acknowledged. It has been argued that mass media outlets have the capability of enlightening heterogeneous audiences, while interpersonal channels have been more influential in affecting behavioural change (Backer et al., 1992; Kreps, 2008; Kreps \& Sivaram, 2009; Okorie, 2011).

Scholars agree that mass media have the power to set agenda and frame issues that affect individuals in any modern society (Hodgetts and Chamberlain, 2006; Leask, Hooker and King, 2010). These scholars also believe that media outlets have substantial influence to identify and report societal health issues that affect socio-cultural and economic development of any nation.

Interestingly, interpersonal networks of communication are also essential channels used in media awareness campaigns. Bero, Grilli and Grimshaw (1998) observe that past studies have found out that interpersonal channels were effective health communication approach. They have the ability to influence opinion and promote positive health behaviours. Therefore, interpersonal channels are essential health communication tools used in media awareness campaigns to promote healthy lifestyle and environment in the society.

This study investigated the effectiveness of information sources such as the mass media (radio, television and print media) and inter- personal networks (health workers, friends, relatives) in media awareness campaigns designed to sensitise women to engage in breast cancer care.

\section{Research Questions}

The study sought to provide answers to the following research questions:

How effective are the mass media as sources of knowledge to breast cancer?

How effective are interpersonal networks as sources of knowledge to breast cancer?

What type of relationship exists between the sources of media awareness and the practice of breast self-examination among women?

\section{Hypotheses}

The study tested the following hypotheses:

$\mathbf{H}_{\mathbf{o}}$ 1: There is no significant relationship between the level of exposure to media information and the level of knowledge of breast cancer.

$\mathbf{H}_{\mathbf{o}}$ 2: There is no significant relationship between the intense use of interpersonal channels and the level of knowledge of breast cancer.

$\mathbf{H}_{\mathbf{o}}$ 3: There is no significant relationship between the sources of awareness and the practice of breast self-examination among women.

\section{Theoretical Framework and Literature Review}

The agenda setting theory and diffusion of innovation theory provided the anchor for this study.

Agenda setting theory is a theory that stipulates that the media have the ability to advise or tell audiences what issues are major and relevant, thus setting the 'agenda'. They can achieve this by choosing what stories to consider news worthy and how prominence and space they give them (Folarin, 1998). Agenda setting portrays a 
very influential authority of the media - the ability to tell us what issues are important. As it relates to issues of breast cancer among women, media experts should frame the issue of breast cancer by highlighting the dangers of contacting such a disease, if women refuse to change their health habits as well as the importance of women engaging in monthly breast self examination in their programs, news reports, feature stories, editorials and documentaries. Through the placement of issues at vital points of newspaper pages as well as broadcasting programs, media experts can frame issues of breast cancer. In addition, emphasis and repetition of issues of breast cancer during television/ radio programs as well as newspaper and magazine reports can increase the awareness and knowledge of breast cancer.

The diffusion of innovation theory focuses on circumstances that determine if a new idea, product, or practice will be accepted by a given culture. Rogers (1995) argues that the theory consists of four elements: invention, diffusion (or communication) through the social system, time and consequences. Thus, the theory has four major interacting factors; the innovation, which is a new idea or practice; a variety of communication channels; certain social systems and a period of time.

As it relates to this study, diffusion of innovation theory places communication at the centre of the process of innovation and change. Communication is conceived of as the process through which information is exchanged, meaning is constructed, and ambiguity is resolved (Rogers \& Kincaid, 1981). According to this perspective, different communication channels make them differentially suited to satisfying individual needs for information, validation and uncertainty reduction.

One of the most common principles in the field of health communication is that mass media are comparatively more essential in creating awareness and knowledge of health- related risks, whereas interpersonal channels are comparatively more efficient in persuading individuals to adopt health behaviours or lifestyles (Rogers, 1995; Yanovitzky \& Blitz, 2000; Kreps, 2008; Kreps \& Sivaram, 2009). This convention is based on the notion that interpersonal channels are more useful and credible in exchanging health information between the source and receiver (Hornik, 1989; Yanovitzky \& Blitz, 2000; Rimal, 2001). Nonetheless, there are those who believe that when there is sufficient individual exposure to persuasive messages, mass media channels are effective in promoting individual health behaviour (Pistrow, Kincard, Riman \& Rimchart, 1997; Yanovitzky \& Blitz, 2000).

Kreps (2005) has also noted that mass media channels play the role of a catalyst to bring change in the development process, and they have become one of the key social and cultural institutions in society. The influence of mass media cuts across social and geographical barriers in society (Soola, 2003; Okorie, 2011), as they disseminate information to target audiences in society. This extends to almost every segment of society that is exposed to their programmes.

Unlike mass media, interpersonal channels focus on interpersonal, face-to-face, communication. Interpersonal networks are usually local and community centred groups, organisations, or a compilation of patrons of a business. Interpersonal networks can also include friends, teachers, relatives, neighbours, opinion leaders, pastors, imams, extension workers and family members.

As a social network, the idea of an interpersonal network is to supply an effortless means to communicate among friends, colleagues and those with common interests. Unlike a typical social network, an interpersonal network usually focuses on a narrow set of interests and tries to draw people together into a local, more personal face to face meeting. These channels are effective agents of change with regard to an 
individual's attitude, skills and behavioural intent.

In sum, mass media and interpersonal channels have been used to promote healthrelated lifestyle behaviours because the focus of public health has undergone a rapid shift from disease treatment to disease prevention or health promotion. The increasing amount of information available through the use of mass media and interpersonal channels has the potential to promote the health behaviour of individuals.

\section{Method of Study}

Survey research design was adopted to achieve the objectives of the study. The design also aided the researcher in gathering quantitative data that provided insights into the subject matter of investigation in the study area. The survey research design is considered suitable for obtaining people's views about why they behave in a particular way and how they will behave in certain conditions. The questionnaire was the quantitative aspect of the research design adopted for the study. The items in the questionnaire measured respondents' demographic characteristics, awareness of breast cancer campaigns, knowledge of breast cancer care, sources of awareness of breast cancer and attitude towards breast cancer and breast self-examination.

This study was carried out in the South-West geo-political zone of Nigeria. The three states purposively selected for the study were Lagos, Oyo and Ekiti States. The total female population for the study consists of women from ages of 25 and 50 years, which constitute 2,493, 793 women in the three states. The breakdown of the total population includes 1,291,685 women who reside in Lagos State, 765,340 women who reside in Oyo State, and 436,768 women who reside in Ekiti State (National Population Commission, 2006).
The choice of the study population of women from ages of 25 to 50 years was because women within this age range are the most vulnerable to breast cancer (WHO, 2008). In addition, various international organisations and groups have spearheaded the need for women within this age range to be aware and knowledgeable about breast cancer and other related issues such as breast self examination, clinical examination and so on (WHO, 2007; IARC, 2008).

The study had a sample size of 600 respondents for a population of women from the ages of 25 to 50 years, which constituted about 1,291,685 women who reside in Lagos; 765,340 women who reside in Oyo State and 436,768 women who reside in Ekiti State (National Population Commission, 2006). The sample size of 600 is higher than the Krejcle and Morgan's recommended sample size of 384 for the population size of 2,493, 793 at 95 percent confidence level and five percent sampling error. Keyton (2001, p.127) has noted that " 384 respondents serve as the sample size for a population of 100,000 people and above at a 95 percent confidence level and 5 percent sampling error".

\section{Results}

The quantitative data for this study provide demographic profile of the respondents and describe the behavioural and belief factors that contribute to the spread of breast cancer among women in Nigeria. A total number of 600 copies of a questionnaire were distributed to the sampled population. However, these results are based on 574 copies of the questionnaire that were properly filled and returned. This represents a 93\% response rate of 574 copies of the questionnaire that were administered to the respondents. Table 1 shows the distribution of women by demographic characteristics: research location, marital status, age of respondents, educational qualification and occupation. These variables are discussed using table 4.1: 
Table 1: Demographic Characteristics of Respondents

\begin{tabular}{|c|c|c|c|c|}
\hline Characteristics & \multicolumn{4}{|c|}{ Percent } \\
\hline \multirow[t]{3}{*}{$\begin{array}{l}\text { 1. Research Location } \\
\text { Lagos State } \\
\text { Ekiti State } \\
\text { Oyo State } \\
\text { Total }\end{array}$} & \multicolumn{4}{|c|}{$\begin{array}{l}41.8 \\
26.0 \\
32.2 \\
100 \\
n=574\end{array}$} \\
\hline & \multicolumn{3}{|c|}{ Research Location } & \multirow[t]{2}{*}{ Percent } \\
\hline & Lagos & Ekiti & Оуо & \\
\hline $\begin{array}{l}\text { 2. Educational Qualifications } \\
\text { Basic education } \\
\text { WAEC/GCE/NECO } \\
\text { Bsc/HND } \\
\text { Msc } \\
\text { PhD. } \\
\text { Total }\end{array}$ & $\begin{array}{l}1.8 \\
18.3 \\
16.4 \\
5.3 \\
0 \\
41.8\end{array}$ & $\begin{array}{l}1.3 \\
11.3 \\
10.2 \\
3.2 \\
0 \\
26.0\end{array}$ & $\begin{array}{l}- \\
14 \\
14.2 \\
4 \\
0 \\
32.2\end{array}$ & $\begin{array}{l}3.1 \\
43.6 \\
40.8 \\
12.5 \\
0 \\
100 \\
n=574\end{array}$ \\
\hline $\begin{array}{l}3 . \text { Age } \\
25-30 \\
31-35 \\
36-45 \\
45-50 \\
\text { Total }\end{array}$ & $\begin{array}{l}7.3 \\
10.1 \\
24.4 \\
0 \\
41.8\end{array}$ & $\begin{array}{l}6.4 \\
5.5 \\
14.1 \\
0 \\
26.0\end{array}$ & $\begin{array}{l}6.2 \\
7 \\
19 \\
0 \\
32.2\end{array}$ & $\begin{array}{l}19.9 \\
22.6 \\
57.5 \\
0 \\
100 \\
n=574\end{array}$ \\
\hline
\end{tabular}

Three states in South-West Nigeria were selected for this study. These three states are characterised by similar languages, beliefs and religions. From the three states studied, Lagos State had the highest number of respondents with $41.8 \%$ of the study sample. This is closely followed by Oyo State with $32.2 \%$ and Ekiti State with $26.0 \%$. This is expected because the National Population Commission reported that Lagos State has the highest population in South-West Nigeria.
Education is the bedrock of health development and promotion. It is a key variable that expands the mental sphere, influences the entirety of the mind and incline women to new ideas. Table 1 (panel 2) also presents the educational qualification of respondents. It shows that $43.6 \%$ of the respondents had WAEC/NECO as their highest level of educational qualification. Only $40.8 \%$ of the respondents had Bsc. or HND degree as their highest level of educational qualification.

Okorie Nelson, Oyesomi Kehinde, Olusola Oyero, Olatunji Rotimi Wiliams and Ebenezer Oludayo Soola (2014), Journal of African Research in Business \& Technology, DOI: 10.5171/2014.152107 
Table 2: Level of Knowledge of Breast Cancer

\begin{tabular}{|l|l|l|}
\hline \multicolumn{2}{|l|}{} & Percent \\
\hline Valid & VERY KNOWLEDGEABLE & 9.4 \\
& SUFFICIENTLY KNOWLEDGEABLE & 39.9 \\
& INSUFFICIENTLY KNOWLEDGEABLE & 50.7 \\
& Total & 100.0 \\
& & $\mathrm{n}=574$ \\
\hline
\end{tabular}

For Table 2, the researcher indentified three levels of knowledge i.e. 'Very Knowledgeable', 'Sufficiently Knowledgeable' and 'Insufficiently Knowledgeable'. The table revealed that $9.4 \%$ of the respondents were very knowledgeable about breast cancer, while $39.9 \%$ of them were sufficiently knowledgeable. However, $50.7 \%$ of the respondents were insufficiently knowledgeable about breast cancer. Hence, a large number of respondents were insufficiently knowledgeable about breast cancer.

Table 3: Respondents' Sources of Awareness

\begin{tabular}{|l|l|}
\hline Sources of Awareness & Percent \\
\hline NEWSPAPER/MAGAZINE & 40.2 \\
TELEVISION & 30.3 \\
RADIO & 12.4 \\
HEALTH WORKERS & 10.1 \\
FAMILY & 3.8 \\
FRIENDS & 3.1 \\
& \\
Total & 100.0 \\
& $\mathrm{n}=574$ \\
\hline
\end{tabular}

In Table 3, the top three sources of information among women about breast cancer include: newspapers/magazine, television and radio. As many as $40.2 \%$ of the respondents indicated that newspapers/magazines were their primary sources of information about breast cancer Also, $30.3 \%$ of the respondents indicated that television was their primary source of information about breast cancer. Only, $12.4 \%$ of the respondents claimed that radio was their primary source information.

\section{Test of Hypotheses}

$\mathbf{H}_{\mathbf{o}}$ 1: There is no significant relationship between the exposure to media information and the level of knowledge of breast cancer 
Table 4a: Correlation test for hypothesis one

\begin{tabular}{|c|c|c|c|c|c|}
\hline & & Value & $\begin{array}{l}\text { Asymp. Std. } \\
\text { Error(a) }\end{array}$ & $\begin{array}{l}\text { Approx. } \\
\text { T(b) }\end{array}$ & Approx. Sig. \\
\hline $\begin{array}{ll}\text { Interval } & \text { by } \\
\text { Interval } & \end{array}$ & Pearson's R & -.130 & .033 & -3.148 & $.002(\mathrm{c})$ \\
\hline $\begin{array}{ll}\text { Ordinal } & \text { by } \\
\text { Ordinal } & \\
\end{array}$ & Spearman Correlation & -.182 & .037 & -4.436 & $.000(c)$ \\
\hline \multicolumn{2}{|l|}{$\mathrm{N}$ of Valid Cases } & 574 & & & \\
\hline
\end{tabular}

Table 4b: Directional Measures for hypothesis one

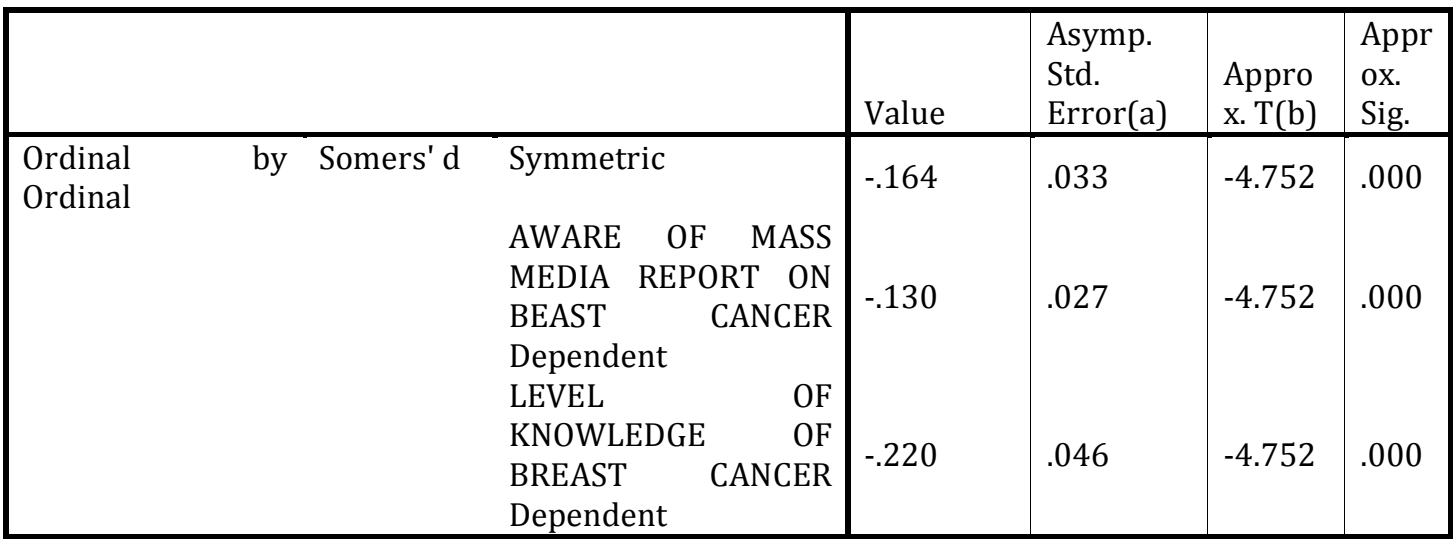

$\mathbf{H}_{\mathbf{o}}$ 2: There is no significant relationship between the intense use of interpersonal channels and the level of knowledge of breast cancer.

Table 5a: Correlation test for hypothesis two

\begin{tabular}{|c|c|c|c|c|c|}
\hline & & Value & $\begin{array}{l}\text { Asymp. Std. } \\
\text { Error(a) }\end{array}$ & $\begin{array}{l}\text { Appro } \\
\text { x. T(b) }\end{array}$ & $\begin{array}{l}\text { Approx. } \\
\text { Sig. }\end{array}$ \\
\hline $\begin{array}{l}\text { Nominal by } \\
\text { Nominal }\end{array}$ & Contingency Coefficient & .311 & & & .000 \\
\hline Interval by Interval & Pearson's R & .297 & .020 & 7.441 & $.000(\mathrm{c})$ \\
\hline $\begin{array}{l}\text { Ordinal by Ordinal } \\
\mathrm{N} \text { of Valid Cases }\end{array}$ & Spearman Correlation & $\begin{array}{l}.316 \\
574\end{array}$ & .021 & 7.965 & $.000(\mathrm{c})$ \\
\hline
\end{tabular}

Okorie Nelson, Oyesomi Kehinde, Olusola Oyero, Olatunji Rotimi Wiliams and Ebenezer Oludayo Soola (2014), Journal of African Research in Business \& Technology, DOI: 10.5171/2014.152107 
Table 5b: Directional Measures for hypothesis two

\begin{tabular}{|c|c|c|c|c|c|c|}
\hline & & & Value & $\begin{array}{l}\text { Asymp. } \\
\text { Std. } \\
\text { Error(a) }\end{array}$ & Approx. T(b) & $\begin{array}{l}\text { Approx. } \\
\text { Sig. }\end{array}$ \\
\hline \multirow{14}{*}{\multicolumn{2}{|c|}{ by Somers'd }} & & .260 & .018 & 8.419 & .000 \\
\hline & & SEEKING & \multirow{10}{*}{.170} & \multirow{10}{*}{.020} & \multirow{10}{*}{8.419} & \multirow{10}{*}{.000} \\
\hline & & INFORMATION & & & & \\
\hline & & FROM & & & & \\
\hline & & INTERPERSONA & & & & \\
\hline & & L NETWORKS & & & & \\
\hline & & ON BREAST & & & & \\
\hline & & CANCER & & & & \\
\hline & & Dependent & & & & \\
\hline & & LEVEL $\quad$ OF & & & & \\
\hline & & KNOWLEDGE & & & & \\
\hline & & OF BREAST & \multirow[t]{3}{*}{.547} & \multirow[t]{3}{*}{.022} & \multirow[t]{3}{*}{8.419} & \multirow[t]{3}{*}{.000} \\
\hline & & CANCER & & & & \\
\hline & & Dependent & & & & \\
\hline
\end{tabular}

$\mathbf{H}_{\mathbf{o}}$ 3: There is no significant relationship between the sources of awareness and the practice of breast self-examination among women.

Table 6a: Correlation test for hypothesis three

\begin{tabular}{|c|c|c|c|c|c|}
\hline & & Value & $\begin{array}{l}\text { Asymp. Std. } \\
\text { Error(a) }\end{array}$ & $\begin{array}{l}\text { Approx. } \\
\text { T(b) }\end{array}$ & Approx. Sig. \\
\hline $\begin{array}{l}\text { Nominal by } \\
\text { Nominal }\end{array}$ & Contingency Coefficient & .296 & & & .000 \\
\hline Interval by Interval & Pearson's R & .219 & .036 & 5.105 & $.000(\mathrm{c})$ \\
\hline $\begin{array}{l}\text { Ordinal by Ordinal } \\
\mathrm{N} \text { of Valid Cases }\end{array}$ & Spearman Correlation & $\begin{array}{l}.269 \\
517\end{array}$ & .027 & 6.327 & $.000(c)$ \\
\hline
\end{tabular}

Okorie Nelson, Oyesomi Kehinde, Olusola Oyero, Olatunji Rotimi Wiliams and Ebenezer Oludayo Soola (2014), Journal of African Research in Business \& Technology, DOI: 10.5171/2014.152107 
Table 6b: Directional Measures for hypothesis three

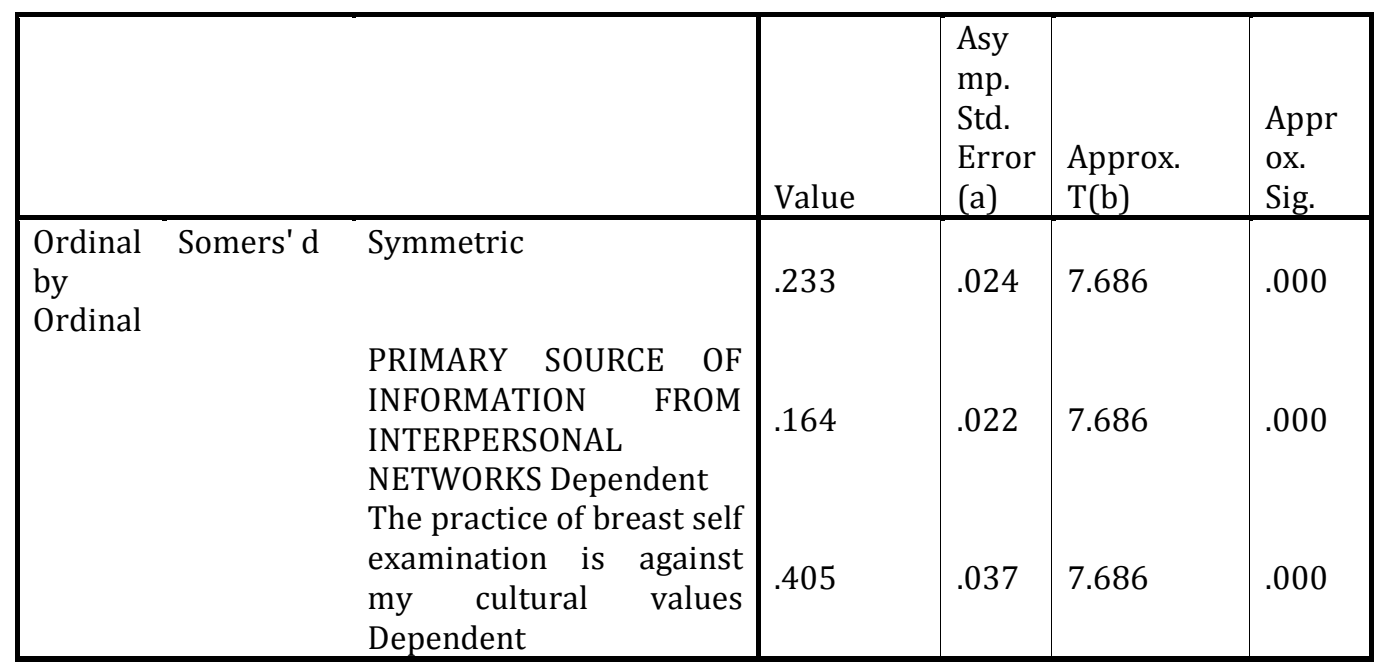

\section{Discussion}

The presentation and analysis of the data have brought a lot of issues to the fore. Some of these issues support as well as mark a departure from existing literature and theory in health communication studies. The first hypothesis which stated, there is no significant relationship between exposure to media information and the level of knowledge of breast cancer was rejected. Correlation analysis on Table $4 \mathrm{a}$ and $\mathrm{b}$ revealed there was a relationship between variables, but the relationship was a weak one. In other words, the results from the Correlation tests at the $5 \%$ alpha level of significance were significant enough to validate or support the hypothesis. Table $4 \mathrm{~b}$ helps to determine the strength and direction between variables i.e. the approximate significance value has 0.00 in its column; one can infer there was a relationship between the variables. In addition, the value statistics helps to determine the strength or the direction of the relationship, it can range from -1 to 1 i.e. negative values indicate a negative relationship, and positive values indicate a positive relationship. From table $4 \mathrm{~b}$, the relationship between variables is a weak one.
This study confirmed that mass media channels constitute the primary sources of information and could significantly influence breast cancer knowledge. In other words, the mass media serve as veritable channels for breast cancer care among women. Also, the fact that mass media are important in promoting health messages cannot be ignored because they serve as primary carriers of health communication messages in the Nigerian society. It is not unlikely to say that mass media are indispensable tools of health communication for breast awareness campaigns.

Against the backdrop of the agenda setting theory, mass media experts could effectively frame issues of breast cancer by informing people of the need to prevent themselves from the disease. Also, the diffusion of innovation theory places communication at the centre of the process of innovation and change. Communication is conceived of as the process through which information is exchanged, meaning is constructed, and ambiguity is resolved (Rogers \& Kincaid, 1981). According to this perspective, different communication channels make them differentially suited to satisfying individual needs for information, validation

Okorie Nelson, Oyesomi Kehinde, Olusola Oyero, Olatunji Rotimi Wiliams and Ebenezer Oludayo Soola (2014), Journal of African Research in Business \& Technology, DOI: 10.5171/2014.152107 
and uncertainty reduction. This theory also stipulates that media outlets are essential health communication tools used to create awareness.

The second hypothesis which tested, there is no significant relationship between the intense use of interpersonal channels and the level of knowledge of breast cancer was rejected. From the available data on table 5 a and $b$, the hypothesis was rejected because the asymmetrical values in the Correlation test were less than 0.05 . Table $5 \mathrm{~b}$ reveals that the relationship between variables is a positive and strong relationship. This study has shown that exposure to interpersonal networks of communication has an impact on the knowledge of breast cancer. The use of interpersonal networks as information sources for breast cancer has been long acknowledged by academic authorities in health communication studies and other related line of research studies.

Interpersonal channels serve as vehicles for health promotion and advocacy for breast cancer information among women in the Nigerian society. Interpersonal channels have the potential to change and form attitudes of women towards ideas or practices. Just like the mass media, interpersonal sources serve as crucial information sources for creating awareness and knowledge of breast cancer in Nigeria. Furthermore, interpersonal channels could be used in forming and changing the attitudes of women to breast cancer and the practice of breast self examination.

The third hypothesis which tested, there is no significant relationship between the sources of awareness and the practice of breast self-examination among women was rejected. This study has revealed that the sources of awareness were significant and effective on the practice of breast selfexamination. Awareness is an important element of communication. It has been widely accepted that the awareness of a disease is essential before any health communication intervention could occur. Thus, awareness could also be seen as an intervention factor for health promotion and advocacy for breast cancer information. This study has shown that the sources of awareness of breast cancer actually influence the practice of breast self-examination. In essence, the use of information sources in heath promotion and interventions cannot be ignored or negotiated. The results have shown that sources of awareness have tremendous influence on the practice of breast self-examination. These results are also in consonance with Yan's (2001) study, in which mass media, such as newspaper, television and radio were identified as the major sources of awareness of breast cancer.

\section{Conclusion}

This study has brought to the fore the inherent features of the diffusion of the innovations' theory. If women in the Nigerian society could seek information about breast cancer from health consultants, medical experts, then the content of this theory should be taken seriously. This study has proved that mass media and interpersonal networks of communication are essential in health interventions for breast cancer and other health related issues. Thus, the core postulations of the diffusion of innovation theory have to be considered in line with health education, advocacy and intervention for breast cancer in Nigeria and the wider world.

Importantly, mass media messages should be incorporated as key machineries in media awareness campaigns for improving breast cancer care among women. This is essential because mass media messages can produce positive changes or prevent negative changes in health-related behaviours of women in South-West Nigeria. 


\section{References}

1. Adaja, T. (2005). Communication and strategies for effective communication. Journal of Communication and Society, 4, 3348.

2. Adebamowo C.A., Ogundiran, T. O., Adenipekun, A.A., Oyesegun, R.A., Campel, O.B., Akang, E.E., Rotimi, C.N., \& Olopade, 0.(2003). Waist-Hip ratio and breast cancer risk in urbanized Nigerian women. Breast Cancer Research, 59(18), 18-24

3. Adeji, O., Smith, O., \& Robies, S. (2009). Direction in development:Public policy and the challenge of non-communicable diseases. Washington DC. World Bank

4. Anaeto, S., Onabanjo, O., \& Osifeso, J. (2008). Models and theories of communication. Lagos African Renaissance Books

5. Backer, T., Rogers, E.M., \& Sopory, P.(1992). Designing health communication campaigns: what works? Wenbury Parks, CA:Sage

6. Chaffee, S.H. (1986). Mass media and interpersonal channels :competitive, convergent or complementary? In Gumpert, G \& Cathart, R, Inter/media, : interpersonal communication in the media world. Newyork: Oxford University Press

7. Cohen, B.C. (1963). The press and foreign policy. Princeton, NJ: Princeton University Press.

8. Fishbein, M., \& Yzer, M.C. (2003). Using theory to design effective health behaviour interventions. Communication Theory, 13, 164-183

9. Folarin, B.(1998).Theories of mass communication.Ibadan, Nigeria.Sceptre Publishing ltd

10. Hodgetts, D. \& Chamberlain, K. (2006). Developing a critical media research agenda for health psychology. Journal of Health Psychology, 11(2), 317-327.

11. Hornik, R. (1993). Public health education and communication as policy instruments for bringing about changes in behavior. Paper prepared for meeting on behavioral and social factors in disease prevention.

12. Keyton, J.(2001). Communication research: asking questions, finding answers. New York McGraw -Hill Company

13. Kreps, G. (2005). The impact of communication on cancer risk, incidence, morbidity,mortality and quality of life. Health Communication, 15, 163-171

14. Kreps, G.(2008). Health communication at the population level: principles, methods and results. In Epstein L, Culture competent care, Jerusalem, Israel: National Institute for Health Policy and Health Service Research

15. Kreps, G. \& Sivaram, R. (2009). Strategic health communication across the continuum of

breast cancer care in limited resource countries. Cancer Supplements, 113(8), 23312337

16. Kunezik, M. (1995). Concept of journalism, north and south. Bonn: FreedrickEbert

17. Lazarsfeld, P. F., Bernard, B., \& Hazel, G. (1944). The people's choice. New York: Duell, Sloan and Pearce Leask, J., Hooker, C. \& King, C. (2010). Media coverage of health issues and how to work more effectively with journalists: A qualitative study. BMC Public Health, 10(535), 2-7

18. Lee, C. (2010). Interplay between media use and interpersonal communications in the context of healthy lifestyle behaviour: reinforcing or substituting. Mass Communication and Society, 13 (1), 48-66 
19. Leslie, J. (2005). Women's role and family health. Retrieved February 17, 2008 from htto://bixbyprogram.ph.ucla.edu/course_CH S246.pdf.

20. Mc Quail, D. (2007). McQuail's mass communication theory. $5^{\mathrm{TH}}$ ed. London:Sage

21. McCombs, M. E., \& Shaw, D. L. (1972) The agenda-setting function of mass media. Public Opinion Quarterly 34:159-170.

22. Okorie ,N. (2011). Mass Media Strategies for Creating Awareness of Breast Cancer, Public Knowledge Journal, Retrievable at http://pkjournal.org/?page_id=1520.3(1),

23. Parkin, D.M., Bray, F., Ferlay, J., \& Pisani, P. (2005).Global cancer statistics CA: $a$ Cancer Journal for Clinicians;55(2):74-108

24. Pictrow, P., Kincaid, D., Riman, I. \& Rimchart, W.(1997). Health communication: lessons from family planning. Westport, CT:Praegar

25. Ricardo, R. (1999). Communication: a meeting ground for sustainable development. Retrieved from

http:/www.fao.org.org.sd/cddirect.

26. Rogers, E. M. (1995). Diffusion of innovations (4th ed.). New York: Free Press.

27. Rogers, E. M. (2003). Diffusion of innovations (5th ed.). New York: Free Press.

28. Rogers, E. M., \& Kincaid, D. L. (1981). Communication networks: Toward a new paradigm for research. New York: Free Press

29. Romer, D. (1994). Using mass media to reduce adolescent involvement in drug trafficking. Pediatrics, 93, 1073-1077

30. Sandelin, K., Apffelstaedt, J, Abdullah, H., Murray, E., \& Ajuluchuku, E.(2002). Breast surgery International: breast cancer in developing countries Scandinavian journal of Surgery, 91, 222-226.
31. Soola, E. O. (2003). Development communication: The past, the present and the future. In Soola, E.O. (Ed), Communicating for development purposes(pp. 9-28). Ibadan: Kraft Book Limited.

32. Southwell, B. G., \& Torres, A. (2006). Connecting interpersonal and mass communication: science news exposure, perceived ability to understand science, and conversation. Communication Monograph, 73 (3), 334-350

33. Story, M. T., Neumark-Stzainer, D. R., Sherwood, N. E., Holt, K., Sofka, D.,Trowbridge, F., \& Barlow, S. E. (2002). Management of child and adolescent obesity: Attitudes, barriers, skills, and training needs among health care professionals. Pediatrics, 110(1), 210-214.

34. WHO (2008). The global burden of disease: 2004 update.

35. Wyn, R., Ojeda, V., Ranji, U., \& Salganicoff, A. , (2003). Women. Work and family: a balancing act. Retrieved September 10,2010 from www.hff.org/womenhealth

36. Yanovitzky, I., and Blitz, C.L (2000). Effect of Media Coverage and Physician Advice on Utilization of Breast Cancer Screening by Women 40 Years and Older. Journal of Health Communication: International, 5(2), 117-134 37. 